\title{
HAK ASASI MANUSIA DALAM KONSTITUSI INDONESIA
}

\author{
Abd. Muni \\ Sekolah Tinggi Agama Islam Miftahul Ulum Tarate Pandian Sumenep \\ adulmuni317@gmail.com
}

\begin{abstract}
Abstrak:
Latar belakang lahirnya sebuah konstitusi yaitu berangkat dari kontrak sosial atau general egreement antara mayoritas rakyat terkait konstruksi yang diidealkan oleh sebuah negara. Konstitusi tersebut dibutuhkan oleh warga negara untuk mengakomudir kepentingan mereka bersama agar dapat dilindungi. Adapun kepentingan yang paling fundamental dari setiap warga negara yaitu perlindungan terhadap Hak Asasi Manusia (HAM) yang menjadi salah satu bagian sentral di dalam konstitusi. Dalam hal ini, konstitusi tidak hanya sebatas memberikan jaminan dan proteksi hitam di atas putih, melainkan wajib memberikan garansi berbagai nilai dan norma yang dijadikan rujukan oleh lembaga peradilan dalam menunaikan tugasnya sebagai Wakil Tuhan di muka bumi.
\end{abstract}

Kata Kunci : Hak Asasi Manusia, Konstitusi, UUD 1945

\section{Abstract:}

The existence of a constitution is from a social contract or general egreement between people related to the idealized construction of a country. The constitution is needed by citizens to communicate their common interests to be protected. The most fundamental interests of citizens are protection of buman rights (HAM) which is one of the important parts of the constitution. In this case, the constitution not only provides guarantees and protection in black and white, but also must provide guarantees of various values and norms used as a reference by the judiciary in fulfilling its duties as God's Representative on earth.

Keywords: Human Rights, constitution, 1945 Constitution.

\section{Pendahuluan}

Yang menjadi bagian penting di dalam dinamika hukum Indonesia, di antaranya tentang HAM dan konstitusi ${ }^{1}$. HAM dan konstitusi dalam konsepsi negara hukum ibarat dua sisi mata uang, berbeda namun menyatu. Dalam pemahaman yang paling masyhur, bahwa adanya hubungan pasti yang berasal dari sifat segala sesuatu, dalam pengertian ini dapat disimpulkan setiap wujud mempunyai hukumnya. Di negara berkembang, sebuah perkembangan diawali munculnya negara kekuasaan (machtstaat) yang didasarkan kepada aturan seorang raja dan berkembang menjadi negara

\footnotetext{
${ }^{1}$ Secara umum konstitusi terdapat dua macam, yaitu konstitusi tertulis dan tidak tertulis. Konstitusi berbeda dengan UUD, dikarenakan sutu kekhilafan dalam pandangan orang mengenai konstitusi pada negara-negara modern sehingga pengertian konstitusi disamakan dengan UUD. Kehilafan ini disebabkan oleh pengaruh faham kodifikasi yang menghendaki agar semua peraturan hukum ditulis, demi mencapai kesatuan hukum, kesederhanaan hukum, dan kepastian hukum. Begitu besar pengaruh paham kodifikasi, sehingga tiap peraturan hukum harus ditulis, dan konstitusi yang ditulis disebut UUD. Dikutip dari Sejarah dan Perkembangan Konstitusi di Indonesia, melaui situs https://mkri.id pada jam 21:18 tanggal 10-04-2020.

Konstitusi menurut Miriam Budiardjo adalah suatu piagam yang menyatakan cita-cita bangsa dan merupakan dasar organisasi kenegaraan suatu bangsa yang di dalamnya terdapat berbagai aturan pokok yang berkaitan dengan kedaulatan, pembagian kekuasaan, lembaga-lembaga negara, cita-cita dan ideologi negara, masalah ekonomi, dan lain sebagainya. Lihat dalam Ni'matul Huda, Ilmu Negara, (Yogyakarta : Rajawali Pers, 2014), 135
}

DOI: https://doi.org/10.35719/aladalah.v23i1.27 
hukum (rechtstaat) $)^{2}$. Maka, dalam pengertian yang sama bahwa otoritas masyarakat hanya sebatas menjalankan kewenangan berdasarkan instruksi dari yang lebih tinggi, dan hukum tersebut mengikat seluruh anggota masyarakat. ${ }^{3}$

Hukum merupakan media terpenting dalam melindungi dan menegakkan HAM dalam sebuah negara. Untuk menjamin terlindungnnya dan tegaknya HAM dalam sebuah negara, maka wajib dipastikan hukum tersebut menjadi instrumen bagi otoritas publik atau negara supaya ada pembatasan dan saling mengontrol dalam menjalankan tugasnya supaya tidak terjadi abuse of power, pada umumnya dalam banyak kasus hal tersebut menjadi embrio terjadinya pelanggaran HAM. ${ }^{4}$

Sebuah konstitusi sangat erat berkaitan dengan pembatasan dan pembagian kekuasaan. Dalam sejarah Revolusi Perancis yang tidak dapat dipisahkan dengan pola pikir Jean Jacques Rousseau sebagaimana dalam magnum opusnya, Du Contract Social, memberikan sebuah gagasan bahwa antara hak warga dan pemerintah diperlukan adanya pembatasan hak dan kewajiban. Rousseau menjelaskan, bahwa selain diri kita sendiri juga harus menyadari pribadi-pribadi lain yang telah membangun negara, yang hidup dalam kebebasan secara alamiah. Yang melatarbelakangi gagasan Rousseau sebagaimana penulis jelaskan, merupakan hasil pemikiran atas kondisi negara absolut di zamannya serta negara yang kerap merampas hak kebebasan tiap-tiap individu. Menurut Rousseau upaya merubah paradigma berbangsa dan bernegara pada saat itu adalah sebuah keharusan dengan mengkonstruksi pembatasan kekuasaan atau konstitusionalisme. Konstitusionalisme memberikan motivasi yang kuat dalam meletakkan prinsip-prinsip fundamental tentang pemerintahan berasaskan konstitusi dan menolak pemerintahan berdasarkan kekuasaan.

Konstitusi yang akan dibahas dalam tulisan ini fokus pada konstitusi dalam arti sempit, yaitu konstitusi yang kita kenal dengan sebutan UUD 1945. Konstitusi di berbagai negara bahkan hampir seluruh negara di dunia ini, memuat berbagai materi dasar termasuk kaidah-kaidah HAM yang diletakkan pada posisi tertinggi dan menjadi materi inti dalam konstitusi.

Adapun HAM dalam praktik konstitusi di berbagai negara mempunyai sistematika yang berbeda-beda, misalnya Amerika Serikat yang memformulasikan HAM dalam amandemen I hingga $\mathrm{X}$ yang dikenal dengan Bill of Rights. Mayoritas konstitusi yang dihasilkan dari produk pergantian rezim mengatur HAM dalam bab khusus, sebagaimana yang terjadi di Filipina dan Afrika Selatan. Hal yang sama terjadi juga di negara Indonesia melalui amandemen II UUD 1945. Ada pula konstitusi yang tidak mngatur HAM dalam bab khusus, melainkan tersebar dalam beberapa Pasal, seperti Australia.

\footnotetext{
2 Terminologi lain dari Negara Hukum adalah Rechtstaat, Etat de droit, dan Rule of Law. Konsepsi Rechtstaat sendiri mengalami perkembangan yang sangat mendasar dari gagasan semula sehingga muncul pandangan khususnya di Jerman, bahwa saat ini istilah tersebut dianggap tidak relevan lagi untuk digunakan. Istilah Etat de droit meskipun merupakan terjemahan dari Rechtstaat, di samping terkait dengan istilah dan konsepsi Etat Legal, substansinya mengandung perbedaan dengan gagasan Rechtstaat (yang klasik). Sedangkan Rule of Law yang semula berkembang di Inggris terutama lewat Dicey, di AS perkembangannya menjadi sangat berlainan degan di negeri asalnya. jika ajaran Rule of Law di Inggris melahirkan praktik Negara hukum yang bercocok dengan prinsip supremasi parlemen (parliamentary model), ajaran Rule of Law di AS melahirkan praktik Negara hukum yang bercocok dengan prinsip supremasi konstitusional (constitutional model). Lihat di prakata I Dewa Gede Palguna, Pengaduan Konstitusional (Constitutional Complaint), (Jakarta : Sinar Grafika, 2013), 17

${ }^{3}$ Muhammad Amin Putra, Perkembangan Muatan HAM dalam Konsitusi di Indonesia, (Jakarta : Fiat Justisia Jurnal Ilmu Hukum UI Volume 9 No. 2, April-Juni 2015), 200

${ }^{4}$ Muhammad Amin Putra, Perkembangan Muatan HAM dalam Konsitusi, 201
} 
Dalam realitas sosial, sering dijumpai ketidak sesuaian antara das sollen ${ }^{5}$ dan das $\operatorname{sein}^{6}$ atau kenyataan. Dari sisi das sollen, konstitusi tercantum berbagai macam asas dan norma, serta perlindungan dan garansi terhadap HAM. Tetapi ketentuan sebagaimana tercantum di dalam das sollen tidak se jalan dengan fakta yang ada, ironisnya sering jumpai keterbelakangan, kemiskinan, bahkan penindasan yang diabaikan oleh penguasa. ${ }^{7}$

Tulisan ini akan membahas tentang HAM dalam konstitusi Indonesia, meliputi; konsepsi HAM sebelum kemerdekaan, konsepsi HAM dalam konstitusi Indonesia, konsekuensi yuridis diaturnya HAM dalam konstitusi, dan perkembangan HAM pasca amandemen.

\section{HAM Sebelum Kemerdekaan}

Secara etimologi, hak merupakan unsur normatif yang dijadikan pedoman berprilaku, melindungi kebebasan, dan menjamin manusia dalam menjaga harkat martabatnya. Sementara asasi adalah sifat yang paling fundamental yang dimiliki setiap manusia. Dengan demikan dapat disimpulkan, bahwa hak asasi merupakan hak yang paling mendasar yang berada pada setiap manusia sejak diciptakan oleh Allah SWT. sebagai fitrah, sehingga tidak satu pun yang dapat mengintervensi apalagi menghilangkannya, seperti hak hidup, hak kemerdekaan, hak milik dan hakhak lainnya.

Kuntjoro Purbopranoto mengartikan HAM sebagai hak-hak yang dimiliki manusia menurut kodratnya, yang tidak dapat dipisahkan dari pada hakikatnya dan karena itu bersifat suci ${ }^{8}$. Menurut Jan Materson dari Komisi PBB sebagaimana dikutip oleh Baharuddin Lopa menegaskan, bahwa HAM adalah hak-hak yang melekat pada diri setiap manusia yang tanpanya mustahil manusia dapat hidup sempurna. ${ }^{9}$ Selanjutnya John Locke yang dikenal sebagai bapak HAM memberikan ta'rif tentang HAM, menurutnya, HAM adalah pemberian langsung dari Tuhan sebagai hak kodrati. Di dalam Undang-undang No. 39 Tahun 1999 tentang Hak Asasi Manusia, mengartian HAM sebagai $:^{1}$

“...Seperangkat hak yang melekat pada hakikat dan keberadaan manusia sebagai mahluk Tuhan Yang Maha Esa dan merupakan anugerahNya yang wajib dihormati, dijunjung tinggi dan dilindungi oleh negara, hukum, Pemerintah, dan setiap orang demi kehormatan serta perlindungan harkat dan martabat manusia".

Konsepsi HAM bukanlah sebuah wacana baru di dalam diskursus politik dan ketatanegaraan Indonesia. Kita dapat menjumpainya dengan jelas dan gamblang dalam riblab sejarah pembentukan bangsa ini, yang mana HAM murupakan bagian penting dalam wacana tersebut. Jauh sebelum kemerdekaan Indonesia ini diproklamasikan, para sesepuh bangsa ini telah menyalakan api

\footnotetext{
${ }^{5}$ Das Sollen adalah apa yang seharusnya sebagai fakta hukum yang diungkapkan oleh para ahli hukum dalam tataran teoritik (law in the books), yakni hukum dalam bentuk cita-cita bagaimana seharusnya. Lihat di https://m.hukumonline.com diakses pada jam 21:27 tanggal 06/04/2020

${ }^{6}$ Das Sein adalah lebih kepada fakta, yaitu hukum yang berkembang dan berproses di masyarakat (law in action). Lihat di https://m.hukumonline.com diakses pada jam 21:27 tanggal 06/04/2020

${ }^{7}$ Bagir Manan dan Susi Dewi Harjianti, Konstitusi dan Hak. Asasi Manusia, (Bandung: Jurnal Ilmu Hukum Universitas Padjajaran Volume 3 No.3, 2016), 448

8 Kuntjoro Purbopranoto, Hak-hak. Asasi Manusia dan Pancasila, (Jakarta : Pradya Paramita,1982), 19 dalam Muhammad Amin Putra, Perkembangan Muatan HAM dalam Konsitusi, 207

9 Baharuddin Lopa, Al-Qur'an dan Hak-hak. Azasi Manusia, (Yogyakarta : Dana Bhakti Prima Yasa), 52

1 Lembaran Negara RI Tahun 9999 Nomor 165, Tambahan Lembaran Negara RI Nomor 3886.
} 
semangatnya dalam menggagas serta memperjuankan harkat dan martabat bangsa Indonesia ke arah yang lebih baik. Gagasan-gagasan tersebut dapat kita talaah dalam Risalah monumentalnya Kartini yang berjudul "Habis Gelap Terbitlah Terang", karya-karya politik yang ditulis oleh H.O.S Cokroaminoto, Agus Salim, Douwes Dekker, Soewardi Soeryaningrat, petisi oleh Sutardjo di Volksraad atau pledoi Soekarno yang berjudul "Indonesia Menggugat" dan Moh. Hatta dengan judul "Indonesia Merdeka" yang dibacakan di hadapan Pengadilan Hindia Belanda. ${ }^{1}$

Adapun eksistensi $\mathrm{HAM}^{1}$ sebelum kemerdekaan ${ }^{2}$ Indonesia, yakni pada era kolonial Belanda diatur dalam Regering reglement Hindia Belanda 1854, yang dalam hal ini ditetapkan dalam $W_{e}{ }^{1}$ Belanda, memuat beberảpa hak asasi, namun dalam Wet itu terdapat perbedaan antara warga keturunan Eropa (European) dangan Pribumi (Inlander en met ben gelijkgesteinden).

Dalam perundang-undangan Belanda, HAM bagi golongan Pribumi cenderung dikebiri yakni tidak seimbang antara porsi jaminan HAM golongan Eropa dengan HAM golongan Pribumi. Hal tersebut termaktub dalam ketentuan Pasal 1 Wetbook van Strafreht voor Nederlands Indie yang memuat asas Nullum poena sine lege, yaitu orang dari golongan pertama hanya dapat dituntut untuk dihukum berdasarkan alasan bahwa ia melanggar ketentuan hukum yang telah ditetapkan pada saat pelanggaran terjadi. ${ }^{1}$

Ketidakseimbangan porsi jaminan HAM tersebut di atas bukan terjadi tanpa alasan. Mengingat negara Indonesia saat itu tengah berada dalam garis kekuasaan penjajahan Belanda, yang bagaimanapun bentuknya penjajahan adalah mimpi buruk bagi Hak Asasi Manusia itu sendiri. Bisa dikatakan muatan HAM dalam wet milik kolonial Belanda belum bisa sepenuhnya menjamin kebutuhan masyarakat Indonesia, jika hak untuk merdeka saja masih menjadi cita-cita. Mengenai HAM pada zaman kolonial Belanda, menurut penulis merupakan alasan mengapa bangsa Indonesia ingin merdeka.

\section{Konsepsi HAM Dalam Konstitusi Indonesia}

Secara historis sejak persiapan hingga berdiri dan pelaksanaan pemerintahan Indonesia dapat ditegaskan, bahwa Indonesia menganut sistem konstitusional sehingga masalah HAM menjadi materi yang sangat penting. Menurut A.A.H. Struycken, eksistensi konstitusi memuat pandangan, keinginan dan perkembangan kehidupan negara oleh toko-tokoh bangsa yang menginginkan terbentuknya negara hukum yang menjamin terlindungnya HAM.

Di dalam kerangka pemikiran negara hukum Indonesia diwujudkan dalam bentuk perlindungan terhadap warga negara dalam UUD Negara Republik Indonesia $1945^{1}$. Dibentuknya

1 T. Mulya Lubis, In Search of Human Rights : legal-Political Dilemmas of Indonesia's New Order, 1966-1990, (Jakarta : Gramedia Pustaka Utama, 1993), 352

1 Istilah HAM sendiri berasal cari istilah droits I'hom (Perancis), menslijke recten (Belanda), fitrab (Arab), dan buman right (Inggris). Istilah buman right semula berasal dari right of human yang menggantikan istilah natural right yang selanjutnya oleh Eleanor Roosevelt diubah denganistilah human right yang memiliki konotasi lebih netal dan universal. Lihat dalam Tititk Triwulan Titik, Pokok-pokok Hukum Tata Negara Indonesia Pasca Amandemen UUD 1945, (Surabaya : Cerdas Pustaka Publisher, 2008), 325

1 Wet dalam KBBI adalah Undång-undang, hukum.

1 Tititk Triwulan Titik, Pokok-pykok Hukum Tata Negara Indonesia, 340

1 Lihat Pembukaan UUD 1945 alinea ke empat : "Kemudian dari pada itu untuk membentuk suatu Pemerintah Negara Indonesia yang melindungi segenap bangsa Indonesia dan seluruh tumpah darah Indonesia dan untuk memajukan kesejahteraan umum, mencerdaskan kehidupan bangsa, dan ikut melaksanakan ketertiban dunia yang berdasarkan kemerdekaan, perdamaian abadi dan keadilan sosial, maka disusunlah Kemerdekaan Kebangsaan 
negara hukum merupakan upaya pembatasan absolutisme seorang raja melalui seperangkat aturan dalam konstitusi. Sri Soemantri mengemukakan, lazimnya sebuah muatan materi konstitusi mencakup 3 hal pokok ; pertama, adanya jaminan terahadap HAM dan warga negaranya. Kedua, ditetapkannya susunan ketatanegaraan suatu negara yang bersifat fundamental. Ketiga, adanya klasifikasi dan pembatasan tugas kewenangan ketatanegaraan (checks and balances). ${ }^{1}$

Di dalam madzhab hukum alam ${ }^{1}$, konsepsi dasar HAM meliputi tiga hal, yaitu: ${ }^{1}$

1. hak hidup (the right to life),

2. hak kemerdekaan (the right to liberty), dan

3. hak milik (the right to life).

Tetapi pada realitasnya, HAM tidak berhenti sampai di situ, HAM terus mengalami transformasi. Franklin D. Roosevelt pada 6 Januari 1941 mengemukakan gagasannya dengan 4 (empat) macam formulasi di dalam forum Kongres Amerika Serikat, yaitu:

1. kebebasan berbicara (freedom of speech),

2. kebebasan dalam beragama (freedom of religion),

3. bebas dari rasa takut (freedom of fear), dan

4. bebas terhadap sesuatu yang diinginkan (freedom of from want).

Berbicara mengenai konsepsi HAM dalam konstitusi di Indonesia tidak dapat dipisahkan dari diskursus panjang antara kelompok yang tidak menyetujui dengan kelompok yang bersikeras agar ketentuan HAM diakomodir dalam muatan materi konstitusi. Adapun kelompok yang tidak menyetujui diwakili oleh Soekarno dan Soepomo, sementara kelompok yang menyetujui diwakili oleh Moh. Hatta dan M. Yamin. Menurut Soekarno dan Soepomo, tidak disetujuinya konsepsi HAM dituangkan dalam Pasal-pasal konstitusi karena negara Indonesia yang akan didirikannya adalah negara yang berasaskan kekeluargaan atau gotong-royong yang menolak individualisme. Dalam istilah Soekarno disebut dengan Philosofische groundslag, atau dalam terminologinya Soepomo dikenal dengan Staatsidee, yang tidak menjadikan ideologi liberalisme dan kapitalisme sebagai rujukan. Mengutip argumentasi Soekarno $:^{1}$

"....... saya minta dan menangis kepada tuan-tuan dan nyonya-nyonya, buanglah faham individualisme itu, janganlah dimasukkan dalam UUD kita yang dinamakan rights of the citizens yang dianjurkan oleh Republik Perancis itu adanya”.

“......buat apa kita membuat grondwet, apa gunanya grondwet itu kalau ia tak dapat mengisi perutnya orang yang hendak mati kelaparan. Grondwet yang berisi droits de I homme et du citoyen itu, tidak bisa menghilangkan kelaparannya orang yang miskin yang hendak mati kelaparan. Oleh karena

Indonesia itu dalam suatu Undang-undang Dasar Negara Indonesia, yang terbentuk dalam suatu susunan Negara Republik Indonesia yang berkedaulatan rakyat dengan berdasar kepada Ketuhanan Yang Maha Esa, Kemanusian yang adil dan beradab, Persatuan Indonesia dan Kerakyatan yang dipimpin oleh hikmat kebijaksanaan dalamPermusyawaratan/Perwakilan, serta dengan mewujudkan suatu Keadilan sosial bagi seluruh rakyat Indonesia".

1 C. Anwar, Teori dan Hukum K\&nstitusi, (Malang : In-Trans Publishing, 2011),. 61

1 Hukum alam adalah suatu kaædah hukum tertinggi yang berlaku di mana saja dan kapan saja, tentang apa yang baik atau yang buruk, yang boleh dilakukan, yang harus dilakukan oleh manusia, yang semuanya itu berasal dari kesadaran dan pemikiran rasional manusia (buman reason), terlepas apakah kaidah-kaidah hukum tesebut diatur atau tidak di dalam peraturan perundang-undangan atau dalam sumber hukum lainnya. Lihat dalam Munir Fuady, Teori-teori (Grand Theory) Dalam Hukum, (Jakarta : Kencana Prenadamedia Group, 2013), 17

1 Tititk Triwulan Titik, Pokok-p8kok Hukum Tata Negara Indonesia, 326

1 Dikutip dari pidato Soekarno 'anggal 15-7-1945 di BPUPKI, berdasarkan naskah yang dihimpun oleh RM. A.B. Kusuma, Labirnya Undang-undang Dasar 1945, (Jakarta : Badan Penerbit FH UI, 2004), 352 
itu, jikalau kita betul-betul mendasarkan negara kita kepada paham kekeluargaan, paham tolong menolong, paham gotong-royong, dan keadilan sosial, enyahkanlah tiap-tiap paham individualisme dan liberalisme dari padanya".

Argumentasi Soepomo dalam penolakan dicantumkannya HAM dalam konstitusi berbeda dengan argumentasi Soekarno. Penolakan Soepomo didasarkan pada pandangannya tentang gagasan negara integralistik, menurutnya mempunyai relevansi dengan karakter dan corak masyarakat Indonesia. Menurut paham tersebut, bahwa negara harus menyatu dengan seluruh warganya, sehingga tidak akan terjadi pertentangan antara satu warga dengan warga lainnya, dan mampu mengatasi seluruh kelompok-kelompok dalam sektor apapun. Dapat disimpulkan dari argumentasi Soepomo mengenai penolakan terhadap rumusan materi HAM dalam konstitusi, yaitu dengan menjadikan negara integralistik sebagai sistem ketatanegraan, maka tidak ada pertentangan antara susuna hukum negara dan susunan hukum individu, mengapa demikian ?, karena individu tidak lain adalah bagian dari roh negara.

Pandangan kedua tokoh di atas, didukung oleh Mahfud MD dan Bambang Sutiyoso. Hal ini berlandaskan bahwa terminologi HAM tidak ditemukan secara eksplisit di dalam pembukaan, batang tubuh, termasuk dalam penjelasannya. Justru menurut Sutiyoso, di dalam konstitusi yaitu UUD 1945 hanya ditemukan pencantuman dengan tegas perkataan hak dan kewajiban warga negara, dan hak-hak DPR.

Semantara argumentasi Moh. Hatta dan M. Yamin untuk memasukkan HAM di dalam konstitusi agar rakyat mempunyai rasa berani menyatakan pendapatnya dan pemerintah tidak bertindak sewenang-wenang. Lebih jauh, Moh. Hatta tidak keberatan atas penolakan terhadap individualisme dan liberalisme, akan tetapi Hatta lebih berhati-hati dikhawatirkan dengan keinginan memberikan kekuasaan seluas-luasnya kepada negara, bisa memicu negara yang akan didirikan terjebak dalam ruang otoritarianisme, sebagaimana argumenstasi Hatta $:^{2}$

“...... tapi satu hal yang saya khawatirkan kalau tidak ada satu keyakinan atau satu pertanggungan kepada rakyat dalam hukum dasar yang mengenai haknya untuk mengeuarkan suara, saya khawatir menghianati di atas UUD yang kita susun sekarang ini, mungkin terjadi satu bentukan negara yang tidak kita setujui. Sebab itu ada baiknya dalam satu pasal, misalnya pasal yang mengenai warga negara disebutkan disebelah hak yang sudah diberikan juga kepada tiap-tiap negara rakyat Indonesia, supaya tiap-tiap warga negara itu jangan takut mengeluarkan suaranya. Yang perlu disebut di sini hak buat berkumpul dan bersidang atau menyurat dan lai-lain. Tanggungan ini perlu untuk menjaga supaya negara kita tidak menjadi negara kekuasaan, sebab kita dasarkan negara kita kepada kedaulatan rakyat.

Sementara Yamin lebih konfrontatif dalam menolak argumentasi yang mendukung tidak dicantumkannya HAM dalam konstitusi. Yamin menyatakan, menolak seluruh alasan yang diajukan untuk tidak memasukan HAM dalam konsepsi undang-undang dasar. Menurut Yamin, aturan dasar tidaklah berhubungan dengan liberalisme, melainkan sebuah legitimasi perlindungan dan jaminan kemerdekaan yang sepatutnya diakui dalam konstitusi Indonesia.

Pandangan Moh. Hatta dan M. Yamin tersebut di atas, didukung oleh Soedjono Sumobroto dan Marwoto, Sumobroto dan Marwoto mengatakan UUD 1945 mengangkat fenomena HAM

2 Dikutip dari pidato Moh. Hatta pada tanggal 15-7-1945 di BPUPKI berdasarkan naskah yang dihimpun oleh RM. A.B. Kusuma, Labirnya Undang-undang, 345 
yang hidup di kalangan masyarakat, atas dasar itu HAM yang tersirat di dalam UUD 1945 bersumber pada falsafah dasar dan pandangan hidup bangsa, yaitu Pancasila ${ }^{2}$. Namun silang pendapat antara kedua kelompok pada akhirnya menemukan kompromi, bahwa Pasal-pasal HAM tetap dimasukkan dalam konstitusi dengan rumusan yang sederhana, tidak elaboratif, dan perlu lagi diatur dengan undang-undang.

Di dalam leteratur lain muatan materi HAM tidak hanya termaktub dalam konstitusi, namun juga diformulasikan dalam beberapa aturan hukum, yaitu $:^{2}$ 1). Tap MPR, seperti Tåp MPR No. XVII Tahun 1998 tentang Pandangan dan Sikap Bangsa Indonesia terhadap HAM dan Piagam HAM Nasional, 2). UU, misalnya UU No. 39 Tahun 1999 tentang Hak Asasi Manusia, 3). Perpu, sebagaimana Perpu No. 1 tahun 1999 tentang Pengadilan HAM, 4). Kepres, misalnya Kepres No. 5 Tahun 2001 tentang Pembentukan Pengadilan HAM Ad Hoc pada PN Jakpus, yang diubah dengan Kepres No 98 tahun 2001.

Berangkat dari berbagai varian argumentasi para tokoh di atas, maka dapat kita tarik keimpulan terkait konsepsi HAM dalam konstitusi Indonesia, bahwa keputusan mencantumkan muatan materi HAM dalam konstitusi bukan persoalan yang sederhana, ada banyak kajian teoritis baik dari perspektif sejarah, filosofis, maupun sosiologis. Bahkan dalam perkembangannya, ketentuan HAM tidak selesai sampai di konstitusi, ada banyak peraturan perundang-undangan yang secara khusus mengatur tentang HAM. Ini lah bukti konkret, bahwa HAM adalah sesuatu yang esensial, yang paling berharga dalam diri manusia dan patut mempunyai perhatian lebih dalam pengaturannya, sebagai rujukan dasar bagi rakyat untuk mendapatkan hak-haknya sebagai manusia.

\section{HAM Pra Amandemen UUD 1945}

Pasca kemerdekaan, UUD 1945 merupakan sebuah wadah HAM yang paling mendasar di Indonesia. Namun, seiring perjalanan bernegara dan berbangsa, Indonesia mengalami perubahan konstitusional dari UUD 1945 menjadi RIS pada tahun 1949-1950. RIS pun tidak berlangsung lama di Indonesia, pada tahun 1950-1959 konstitusi kembali berubah menjadi UUDS. RIS adalah konstitusi federal yang dihasilkan dari Konferensi Meja Bundar yang memuat ketentuan hak asasi yang rinci. Selain karena faktor adanya tuntutan terkait kekhawatiran terjadinya pembataian kemanusiaan sebagaimana yang pernah terjadi menjelang dan selama Perang Dunia II, rincian hak asasi dalam RIS tidak terlepas dari pengaruh Universal Declaration of Human Rights yang diadopsi pada tanggal 10 Desember 1948.

UUDS secara yuridis disebut sebagai perubahan RIS, bukan penggantian atau pun pembentukan UUD baru, meskipun dalam faktanya UUDS 1950 merupakan susunan baru RI, karena kembali kapada konsepsi negara kesatuan. Adapun mikanisme perubahan konstitusi ini, berdasarkan Mosi Integral Mohammad Natsir (Ketua Fraksi Partai Masyumi di Dewan Perwakilan Rakyat RIS). Terdapat dua prinsip sebagai petunjuk perubahan RIS menjadi UUDS 1950.

1. Kesepakatan hanya meniadakan ketentuan-ketentuan yang bersifat federalistik. Sementara ketentuan HAM bukan unsur yang bersifat federalistik, oleh sebab itu tetap dipertahankan sebagai muatan materi UUDS 1950.

\footnotetext{
2 Majda El-Muhtaj, Hak Asasi Manusia dalam Konstitusi Indonesia, (Jakarta: Prenada Media, 2005),95.

2 Tititk Triwulan Titik, Pokok-połeok Hukum Tata Negara Indonesia, 338-339
} 
2. Kesepakatan yang dibuat pemerintah RIS dengan Pemerintah RI Yogyakarta menyetujui dimasukkannya prinsip-prinsip fundamental yang terdapat dalam UUD 1945, seperti prinsip demokrasi ekonomi. ${ }^{2}$ 3

Di dalam UUD 1945 pra amandemen tersusun atas Pembukaan dan Batang Tubuh yang terdiri dari 37 Pasal, empat Aturan Peralihan, dua Aturan Tambahan, dan penjelasan. Sementara HAM sendiri dimuat dalam Pembukaan dan Batang Tubuh Konstitusi.

1. Dalam Pembukaan

HAM dalam Pembukaan UUD 1945 termuat dalam tiap-tiap Alinea ${ }^{2}$

a. Alinea $\mathrm{I}^{2}$, merupakan hakikat penğakuan akan adanya kebebasan untuk merdeka (freedom of be free). Dengan kata lain, isi dan makna Alinea I menyatakan bahwa ; bangsa Indonesia berprinsip anti kolonialisme, kemerdekaan adalah hak segala bangs, bangsa Indonesia bertekad untuk merdeka, dan bertekad akan berjuwang melawan setiap bentuk penjajahan.

b. Alinea $\mathrm{II}^{2}$, disebutkan Indonesia sébagai negara yang adil, kata adil di sini adalah kata sifat yang menunjukkan pada salah satu tujuan dari negara hukum untuk mencapai atau setidaknya mendekati keadilan. Apabila prinsip negara hukum ini benar-benar diimplementasikan, maka HAM tersebut tidak hanya menjadi lipstick jargon kemanusiaan.

c. Alinea $\mathrm{III}^{2}$, berdasar pernyataan "atäs berkat rabmat Allab Yang Maha Kuasa", menjadi bukti bahwa Negara Indonesia mengakui nilai-nilai religius, yang menjadi dasar dari negara maupun dasar moral Negara. Pengakuan nilai moral yang terkandung dalam pernyataan "didorong oleh keinginan lubur supaya berkehidupan kebangsaan yang bebas" mengandung makna, bahwa negara dan bangsa Indonesia mengakui nilai-nilai moral dan hak kodrat segala bangsa.

d. Alinea IV ${ }^{2}$, dalam Alinea keempat in̊i memuat prinsip-prinsip serata pokok-pokok kaidah pembentukan pemerintahan negara Indonesia, sebagaimana yang disimpulkan dalam kalimat "....kemudian dari pada itu untuk membentuk suatu pemerintahan negara Indonesia...". Dengan kata lain, negara meneguhkan pengakuan dan perlindungan terhadap hak asasi dalam segala bidang, yaitu ; politik, hukum, sosial, kultur, dan ekonomi.

2. Dalam Batang Tubuh UUD 1945

2 Bagir Manan dan Susi Dewi Harjianti, Konstitusi dan Hak. Asasi Manusia, 464

2 Tititk Triwulan Titik, Pokok-pykok Hukum Tata Negara Indonesia, 341

2 Bahwa sesungguhnya kemerdékaan itu ialah hak segala bangsa dan oleh sebab itu, maka penjajahan diatas dunia harus dihapuskan karena tidak sesuai dengan perikemanusiaan dan perikeadilan.

2 Dan perjuangan pergerakan kemerdekaan Indonesia telah sampailah pada saat yang berbahagia dengan selamat sentosa mengantarkan rakyat Indonesia ke depan pintu gerbang kemerdekaan negara Indonesia, yang merdeka, bersatu, berdaulat, adil dan makmur.

2 Atas berkat rahmat Allah Yang Maha Kuasa dan dengan didorongkan oleh keinginan luhur, supaya berkehidupan kebangsaan yang bebas, maka rakyat Indonesia menyatakan dengan ini kemerdekaannya.

2 Kemudian daripada itu untuk ${ }^{8}$ membentuk suatu pemerintah negara Indonesia yang melindungi segenap bangsa Indonesia dan seluruh tumpah darah Indonesia dan untuk memajukan kesejahteraan umum, mencerdaskan kehidupan bangsa, dan ikut melaksanakan ketertiban dunia yang berdasarkan kemerdekaan, perdamaian abadi dan keadilan sosial, maka disusunlah kemerdekaan kebangsaan Indonesia itu dalam suatu Undang-Undang Dasar negara Indonesia, yang terbentuk dalam suatu susunan negara Republik Indonesia yang berkedaulatan rakyat dengan berdasar kepada : Ketuhanan Yang Maha Esa, kemanusiaan yang adil dan beradab, persatuan Indonesia, dan kerakyatan yang dipimpin oleh hikmat kebijaksanaan dalam permusyawaratan/perwakilan, serta dengan mewujudkan suatu keadilan sosial bagi seluruh rakyat Indonesia. 
Dalam batang tubuh UUD 1945 setidaknya terdapat 7 Pasal yang mengatur langsug HAM. Sekalipun hanya terdapat 7 Pasal, namun pasal-pasal tersebut merupakan hal yang sangat esensial. Pasal-pasal sebagimana yang dimaksud di atas, yaitu : ${ }^{2}$

a. Pasal 27 ayat $(1)^{3}$, yang mengatur tentang hak persamaan dalam hukum dan penghidupan yang layak bagi kemanusiaan. Yang dimaksud dengan prinsip persamaan di dalam hukum ini mempunyai persamaan yang sangat dekat dengan prisip equality before the law, yang dalam arti sederahana semua orang sama di hadapan hukum. Asas persamaan di hadapan hukum merupakan asas dimana terdapat suatu kesetaraan dalam hukum pada setiap individu tanpa ada seatu pengecualian sedikitpun.

b. Pasal 27 ayat $(2)^{3}$, mengamanatkan behwa ${ }^{1}$ segenap warga negara berhak atas penghidupan yang layak bagi kemanusiaa. Oleh sebab itu, pemerintah selaku pemegang otoritas tertinggi berkewajiban untuk menciptakan lapangan pekerjaan yang layak serta menghidupi warga negaranya.

c. Pasal $28^{3}$, mengatur tentang kebeBasan dalam berserikat, berkumpul, dan mengeluarkan pendapat secara lisan maupun tulisan. Di dalam negara demokrasi, ketiga hak asasi ini merupakan hak-hak yang sangat penting dan berarti bagi warga negaranya. Kebebasan berserikat menjadi utopis bila konstitusi tidak mengamanatkan kebebasan untuk mengeluarkan pendapat. UUD 1945 sendiri mengharuskan hal tersebut diatur dalam undang-undang yang secara khusus memuat ketentuan HAM. Oleh sebab itu, pemerintah beserta DPR merumuskan UU No. 3 Tahun 1975 sebagai pelaksana Pasal 28 khususnya kebebasan berserikat (freedom of association).

d. Pasal $29^{3}$, memberikan ketentuan ${ }^{3}$ tentang kebebsan untuk memeluk agama. Pada ayat 2 disebutkan bahwa negara memberikan jaminan kemerdekaan tiap-tiap penduduk memeluk agama dan beribadat sesuai keyakinannya tanpa ada unsur paksaan dari pihak manapun, serta tidak ada yang bisa melarang dan mencegah seseorang untuk memilih agama yang diimaninya. Akan tetapi, kebebasan dalam memeluk dan beribadat di sini telah ditegaskan dalam ayat 1, bahwa "negara berdasarkan ketuhanan Yang Maba Esa", artinya kebebasan tesebut yang berkorelasi dengan suatu agama yang mengimani ke-Esa-an Tuhan.

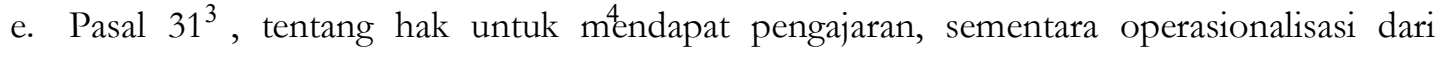
ketentuan ini tertuang dalam UU No. 12 Tahun 2003 tentang Sistem Pendidikan Nasional.

2 Tititk Triwulan Titik, Pokok-po\%ok Hukum Tata Negara Indonesia, 341-343

${ }^{3}$ Segala warga negara bersamaah kedudukannya di dalam hukum dan pemerintahan dan menjunjunghukum dan pemerintah itu dengan tidak ada kecualinya.

Diakses di https://luk.staff.ugm.ac.id/atur/UUD45-Awal.pdf pada jam 17:39 tanggal 10-04-2020.

3 Tiap-tiap warga negara berhak ${ }^{1}$ atas pekerjaan dan penghidupan yang layak bagi kemanusian.

3 Kemerdekaan berserikat dan ${ }^{2}$ berkumpul, mengeluarkan pikiran dengan lisan dan tulisan dan sebagainya ditetapkan undang-undang.

3 (1) Negara berdasarkan atas Ketuhanan Yang Maha Esa

(2) Negara menjamin kemerdekaa tiap-tiap penduduk untuk memeluk agamanya masing-masing dan untuk beribadat menurut agamanya dan dan kepercayaanya itu.

3 (1) Tiap-tiap warga negara befhak mendapat pengajaran.

(2) Pemerintah mengusahakan dan menyelenggarakan satu sistem pengajaran nasional, yang diatur dalam undangundang. 
f. Pasal $32^{3}$. Para perumus UUD ${ }^{5} 1945$ menyadari peran penting kebudayaan dalam membentuk jati diri masyarakat dan bangsa Indonesia pada khususnya, serta bagi modernitas dan kemajuan bangsa pada umumnya. Pengembangan budaya Indonesia bukan hanya menjadi tanggungjawab pemerintah, tetapi juga menjadi tanggungjawab bersama masyarakat.

g. Pasal $33^{3}$ ini memuat ketentuan ${ }^{6}$ hukum tentang hak-hak ekonomi. Pasal tersebut menegaskan bahwa berdasar kemakmuran masyarakat adalah utama, perekonomian disusun berdasarkan asas kekeluargaan, cabang-cabang produksi penting bagi negara dan meguasai hajat hidup orang banyak harus dikuasai negara.

h. Pasal $34^{3}$ memuat tentang kesejahteraan sosial. Di dalam rumusan tersebut terkandung maksud untuk lebih mendekatkan gagasan negara kesejahteraan dalam pembukaan UUD 1945 ke dalam realitas sosial. Negara Indonesia sebagai negara kesejahteraan, berarti terdapat tanggungjawab negara untuk mengembangkan kebijakan di berbagai bidang serta menigkatkan kualitas pelayanan umum yang baik melalui penyediaan berbagai fasilitas yang dibutuhkan oleh masyarakat.

Pada mulanya, suasana HAM berdasarkan RIS dan UUDS 1950 berjalan dengan baik sebagaimana terdahulu. Pengekangan mulai terjadi sejaka pemerintah menyatakan keadaan darurat. Masa berlangsungnya keadaan darurat tidak sebentar, dan baru berakhir pada tahun 1963 an (era UUD 1945). Reformasi merupakan upaya pemulihan hak asasi melalui amandemen UUD 1945, TAP MPR, serta peraturan perundang-undangan lainnya. Akan tetapi, kebebasan yang dinikmati terhitung sejak reformasi lebih dominan berkaitan dengan kebebasan individu dan politik. Sementara kebebasan hak asasi di sektor sosial dan ekonomi masih sekedar anganangan, bahkan lebih ironis lagi ada yang berpendapat, bahwa jurang antara miskin dan kaya semakin meruncing. Perlu disadari bahwa semua ini terjadi bukan semata-mata persoalan minimnya anggaran, namun lebih kepada mismanagement, maladministration, minimnya rasa tanggungjawab, dan rendahnya nilai-nilai kemanusiaan. Ini merupakan penyakita luar biasa kronis yang menghinggapi penyelenggara negara dan bisa menular dengan cepat kepada siapapun yang memiliki hubungan dengan kekuasaan. ${ }^{3}$

8

\section{Perkembangan HAM Pasca Amandemen}

Sebelum kita masuk pada perkembangn HAM era reformasi, dirasa penting untuk mengulas faktor terjadinya reformasi konstitusi di Indonesia. Ketika memasuki Era Orde Baru perkembangan HAM di Indonesia tidak begitu signifikan, hal ini dipahami kepemimpinan Soeharto yang dimulai sejak 1966 masih dihantui kompleksitas persoalan politik, kemanan, dan perekonimian dalam negeri. Dalam praktik bernegara, implementasi HAM secara baik dan bertanggungjawab sangat bergantung pada suasana political will, political commitmen, dan political action dari pelanggaran

3 Pemerintah memajukan kebudayaan nasional Indonesia.

3 (1) Perekonomian disusun selbagai usaha bersama berdasarkan atas asas kekeluargaan.

(2) cabang-cabang produksi yang penting bagi negara dan yang menguasai hajat hidup orang banyak dkuasai oleh negara.

(3) Bumi dan air dan kekayaan alam yang terkandung di di dalamnya dikuasai oleh negara dan dipergunakan untuk sebesar-besarnya kemakmuran rakyat.

3 Fakir miskin dan anak-anak yång terlantar dipelihara oleh negara.

3 Bagir Manan dan Susi Dewi Hårjianti, Konstitusi dan Hak. Asasi Manusia, 464 
negara. Pada masa itu, perkembangan HAM yang cenderung lamban perlu diakui karena pengaruh konfigurasi politik yang refresif. Sehingga tidak hanya HAM yang tidak dilaksanakan, namun juga penegakannya cendrung diabaikan. ${ }^{3}$

Meurut Hans Kelsen dalam memformulasikan konsepsi negara hukum dalam kaitannya dengan demokratisasi dan HAM, mengajukan empat syarat : ${ }^{4}$

1. Negara yang kehidupannya sejalan dengan konstitusi dan undang-undang, yang proses perumusannya dilakukan oleh parlemen. Dan anggota-anggota parlemen tersebut dipilih secara oleh rakyat.

2. Negara yang mengatur mekanisme pertanggungjawaban atas setiap kebijakan dan tindakan yang dilakukan oleh elit negara.

3. Negara yang menjamin kemerdekaan kekuasaan kehakiman.

4. Negara yang melindungi HAM.

Berkaitan dengan hal tersebut, dalam hal perlindungan dan penegakan HAM, amandemen UUD 1945 memberikan jaminan yang lebih komprehensif. Hal ini berbeda dengan UUD 1945 sebelum amandemen yang hanya memuat pasal-pasal HAM secara garis besar saja. Di dalam UUD 1945 setelah amandemen selain mengatur HAM secara garis besar, UUD tersebut juga mencantumkan bab khusus HAM, yaitu BAB XA yang memuat sebanyak 10 pasal mulai Pasal 28A hingga Pasal 28J.

Adapun dampak amandemen memberikan penegasan bahwa, perlindungan, pemajuan, penegakan, dan pemenuhan HAM adalah tanggungjawab negara, khususnya pemerintah, walaupun pada pada tahun pertama perjalanan reformasi ditandai dengan konflik horizontal ${ }^{4}$, antara lain di Ambon, Poso, dan Kalimanan, di mana pelanggaran HAM dilakukan oleh kelompok-kelompok masyarakat sendiri.

Di dalam perubahan kedua UUD 1945, pengaturan mengenai HAM tercantum dalam satu bab tersendiri yang terdapat dalam BAB XA dengan 10 pasal dan 24 ayat. Terkait jaminan penegakan HAM sebagai sebuah pilar negara hukum. Adapun rumusan mengenai HAM ini sangat detail yang mencakup seluruh aspek HAM yang diakui secara universal. Seluruh HAM yang termuat di dalam BAB XA UUD NRI 1945 keberlakuannya dapat dibatasi. HAM juga diperkuat dengan Pasal 28J sebagai pasal penutup dari seluruh ketentuan yang mengatur HAM. Sistematika pengaturan HAM dalam UUD NRI 1945 ini sejalan dengan sistematika pengaturan HAM dalam Universal Declaration of Human Right yang juga memposisikan pasal pembatasan HAM sebagai pasal penutup, yaitu Pasal 29 ayat $(2)^{4}$. 60.

${ }^{3}$ Majda El Muhtaj, Dimensi-dimensi HAM Mengurai Hake Ekonomi, Sosial dan Budaya, (Jakarta: Rajawali Pers, 2008),

4 Tititk Triwulan Titik, Pokok-pokok Hukum Tata Negara Indonesia, 343

4 Konflik horizontal merupakah terminologi konflik yang terjadi antar individu atau kelompok organisasi yang memiliki kedudukan yang sama atau setara. Konflik ini dapat terjadi sebagai akibat dari kurangnya komunikasi dua pihak yang setara, benturan persepsi yang ada di antara dua belah pihak yang setara yang dapat berupa benturan pendapat dan ideologi. Diakses melalui https://id.m.wikipedia.org

4 yang berbunyi, : in the exercise ff his rights and freedoms, everyone shall be subject only to such limitations as are determined by law solely for the purposes of securing due recognition and respect for the rights and freedoms of others and of meeting the just requirements of morality, public order and the general walfare in a democratic society. Dikutip dari Yeni Handayani, Pengaturan Hak. Asasi Manusia Dalam Konstitusi Indonesia Dan Konstitusi Amerika Serikat, (Jurnal Rechts Vinding : Naskah diterima : 23 September 2014; disetujui : 13 Oktober 2014), 3 
HAM yang diatur dalam perubahan kedua UUD NRI 1945 tidak ada yang bersifat mutlak, temasuk hak asasi yang diatur dalam Pasal 28I ayat (1). Pembatasan terkairt HAM di Indonesia memberikan kejelasan bahwa tidak ada satu pun HAM di Indonesia yang bersifat mutla tanpa batas. HAM yang termuat dalam UUD NRI 1945 dapat digolongkan dalam empat kelompok : ${ }^{4}$

1. Hak sipil dan politik

2. Hak ekonomi

3. Hak sosial dan budaya

4. Hak atas pembangunan

Selain tersebut di atas, ketentuan HAM terdapat hak yang dikategorikan sebagai hak yang tidak dapat dikurangi dalam keadaan apapun yang meliputi : ${ }^{4}$

1. Hak untuk hidup

2. Hak untuk tidak disiksa

3. Hak kemerdekaan pikiran dan hati nurani

4. Hak beragama

5. Hak untuk tidak diperbudak

6. Hak untuk diakui sebagai pribadi di hadapan hukum

7. Dan hak untuk tidak dituntut atas dasar yang berlaku surut.

Sebelum amandemen UUD 1945, tepatnya pada tahun 1988-1990 yaitu pada masa pemerintahan Presiden BJ Habibie, telah dikeluarkan TAP MPR RI No. XVII/1998 mengenai HAM yang di dalamnya tercantum Piagam HAM Bangsa Indonesia dalam sidang istimewa MPR RI 1998, dan dilanjutkan dengan undang-undang UU No. 39 Tahun 1999 tentang HAM. Ketentuan yang termuat di dalam kedua peraturan perundang-undangan tersebut telah mengakomodir DUHAM. Apa yang termuat dalam amandemen UUD 1945 pasal 28A hingga pasal 28J telah merujuk pada kedua peraturan perundang-undangan tersebut, dengan rumusan kembali secara sistematis.

Ketentuan HAM dalam UUD NRI 1945 yang menjadi basic law adalah norma tertinggi yang harus dipatuhi oleh negara. Karena letaknya dalam konstitusi, maka seluruh ketentuan terkait HAM harus dihormati dan dijamin pelaksanaannya oleh negara. Hal tersebut menjadi konsekuensi yuridis dirubahnya muatan materi konstitusi terkait HAM, sehingga negara tidak bisa beralasan apapu untuk tidak mentaati ketentua-ketentuan norma tersebut. Oleh sebab itu, Pasal 28I ayat (4) UUD 1945 menegaskan bahwa perlindungan, pemajuan, penegakan, dan pemenuhan HAM adalah tanggungjawab negara, khususnya pemerintah.

Namun perlu diingat, bahwa kebabasan dan hak-hak warga negara di sini bukan tidak ada batasannya, pengaturan mengenai HAM dalam konstitusi antara hak dan kewajiban warga negara diberikan porsi yang seimbang. Kebebasan HAM terhadap manusia lainnya dibatasi oleh undangundang. Pembatasan atas pelaksanaan HAM hanya dapat ditetapkan dengan undag-undang dengan maksud dan tujuan semata-mata untuk menjamin pengakuan dan penghormatan atas hak dan kebebasan orang lain dan untuk memenuhi tuntutan yang adil sesuai pertimbangan moral, nilainilai agama, keamanan, dan ketertiban umum dalam masyarakat demokratis. Inilah yang dimaksud

4 Ibid, hal. 4

4 Yeni Handayani, Pengaturan Hak. Asasi Manusia Dalam Konstitusi Konstitusi, 4 
dengan tidak ada bak yang dapat dilaksanakan secara mutlak, karena dibalik hak kita ada hak-hak orang lain yang wajib kita perhatikan sesuai garis yang telah ditentukan dalam falsafah Pancasila.

\section{Kesimpulan}

Di dalam kehidupan berbangsa dan bernegara, salah satu aspek penting adalah keberadaan konstitusi. Hal ini bersifat fundamental karena konstitusi memuat adanya pengaturan perlindungan HAM bagi warga negaranya. Salah satunya di Indonesia, yang dalam lintasan sejarah terdapat empat fase berlakunya konstitusi, diantaranya UUD 1945, RIS 1949 dan UUDS 1950, UUD 1945 dan UUD NRI 1945 amandemn 1-4.

Ketentuan HAM dalam UUD NRI 1945 yang menjadi basic law adalah norma tertinggi yang harus dipatuhi oleh siapapun. Karena letaknya berada dalam konstitusi, maka seluruh ketentuan terkait HAM harus dihormati dan dijamin pelaksanaannya oleh negara. Hal tersebut menjadi konsekuensi yuridis dirubahnya muatan materi konstitusi terkait HAM, sehingga negara tidak bisa beralasan apapu untuk tidak mentaati ketentua-ketentuan norma tersebut.

\section{Daftar Pustaka}

Anwar, C, Teori dan Hukum Konstitusi, (Malang : In-Trans Publishing, 2011)

El-Muhtaj, Majda, Hak Asasi Manusia dalam Konstitusi Indonesia, (Jakarta: Prenada Media, 2005) , Majda, Dimensi-dimensi HAM Mengurai Hak Ekonomi, Sosial dan Budaya, (Jakarta: Rajawali Pers, 2008)

Fuady, Munir, Teori-teori (Grand Theory) Dalam Hukum, (Jakarta : Kencana Prenadamedia Group, 2013)

Handayani, Yeni, Pengaturan Hak. Asasi Manusia Dalam Konstitusi Indonesia Dan Konstitusi Amerika Serikat, (Jurnal Rechts Vinding : Naskah diterima : 23 September 2014; disetujui : 13 Oktober 2014)

Kusuma, RM. A.B., Labirnya Undang-undang Dasar 1945, (Jakarta : Badan Penerbit FH UI, 2004)

Lembaran Negara RI Tahun 1999 Nomor 165, Tambahan Lembaran Negara RI Nomor 3886.

Lopa, Baharuddin, Al-Qur'an dan Hak-hak. Azasi Manusia, (Yogyakarta : Dana Bhakti Prima Yasa)

Lubis, T. Mulya, In Search of Human Rights : legal-Political Dilemmas of Indonesia's New Order, 1966-1990, (Jakarta : Gramedia Pustaka Utama, 1993)

Manan, Bagir dan Harjianti, Susi Dewi, Konstitusi dan Hak Asasi Manusia, (Bandung : Jurnal Ilmu Hukum Universitas Padjajaran Volume 3 No.3, 2016)

Ni'matul Huda, Ilmu Negara, (Yogyakarta : Rajawali Pers, 2014)

Palguna, I Dewa Gede, Pengaduan Konstitusional (Constitutional Complaint), (Jakarta : Sinar Grafika, 2013),

Purbopranoto, Kuntjoro, Hak-bak Asasi Manusia dan Pancasila, (Jakarta : Pradya Paramita,1982)

Putra, Muhammad Amin, Perkembangan Muatan HAM dalam Konsitusi di Indonesia, (Jakarta : Fiat Justisia Jurnal Ilmu Hukum UI Volume 9 No. 2, April-Juni 2015)

Titik, Tititk Triwulan, Pokok-pokok Hukum Tata Negara Indonesia Pasca Amandemen UUD 1945, (Surabaya : Cerdas Pustaka Publisher, 2008)

Undang-undang No. 39 Tahun 1999 tentang Hak Asasi Manusia

UUD Negara Republik Indonesia Tahun 1945 
AL-ADALAH, Vol. 23 No.1, April 2020

Kamus Besar Bahasa Indonesia

https://id.m.wikipedia.org

https://mkri.id

https://luk.staff.ugm.ac.id/atur/UUD45-Awal.pdf

https://m.hukumonline.com 